\title{
В.О. Рябов
}

\section{Підборідні канали і слух дельфіна}

\begin{abstract}
Пороги виявлення коротких широкосмугових акустичних імпульсів з максимумом енергї на частотах 8, 16, 30 і 100 кГи були виміряні в поведінковому експерименті у дельфіна афаліна (Tursiops truncatus p.) у закритому басейні. Показано, щьо, при акустичному екрануванні підборідних каналів пороги погіршуються на 30, 34, 40 і 50 дБ відповідно. Отримані в роботі нові оригінальні результати вказують на те, щзо підборідні канали являють собою унікальний звукопровідний шлях, по якому звуки в смузі частот приблизно від 6 кГи і до 160 кГц (з огляду на широкосмуговість стимулів) проходять у жировий тяж мандибулярного каналу. У зв'язку з цимм припущення про те, щуо морфологічні структури нижньої щелепи являють собою спеціалізований периферичний відділ слуху дельфіна, щзо було засновано на вивченні морфологіі і результатах моделювання, у світлі отриманих результатів має додаткове експериментальне підтвердження. Підборідні канали відіграють роль зовнішніх слухових проходів і проводять весь діапазон звуків слуху дельфіна в жировий тяж мандибулярного каналу. По жировому тяжу звуки передаються на латеральну стінку барабанної кісти і на завиток. Виходячи з морфологіі, можна припустити наявність подібного механізму звукопроведения в Odontoceti. Ключові слова: дельфін, слух, підборідні канали, жировий тяж, мандибулярний канал, звукопроведення.
\end{abstract}

\section{ВСТУП}

Велика кількість праць і запропонованих до дійсного часу гіпотез показують значний інтерес дослідників до вивчення механізмів слуху зубатих китів. Низка авторів вважає, що звук проходить на завииок через зовнішні слухові проходи і середнє вухо, хоча $є$ також думка, що слухові проходи взагалі не можуть брати участь у проведенні звуку до середнього вуха [14] чи служать для проведення сигналів з частотами нижче ніж 30 кГц [6]. Інші автори припускають, що звук може передаватися по жировому тяжу мандибулярного каналу безпосередньо на барабанну кістку, виключаючи зовнішні слухові проходи і барабанні зв'язки [6, 14, 15, 16]. Норрис [15] припустив, що звук може передаватися в жировий тяж мандибулярного каналу через підборідні отвори. Хоча трохи пізніше він висуває іншу гіпотезу, яка нині є загальновизнаною, про те, що звук, передається (C) В.О. Рябов в жировий тяж безпосередньо через задньолатеральну стінку кістки нижньої щелепи, у ділянці, яку він назвав “акустичним вікном" [16]. По жировому тяжу звук передається на латеральну стінку барабанної кістки, де їі товщина мінімальна, i стінка відіграє роль барабанної перетинки, передаючи звукові коливання на молоточок середнього вуха $[10,11,14,15]$. Було також показано, що акустичне стимулювання нижньої щелепи збуджує значні викликані потенціали в центральній слуховій системі дельфіна [6, 14]. Однак ділянки максимальної чутливості поверхні нижньої щелепи до звуків, випромінюваним контактно крапковим випромінювачем, у кожній з праць $[6,7,13,14]$ різні, а отримані результати не пояснюють механізм звукопроведення. Є також роботи $[12,17]$, у яких автори припускають, що зубаті кити приймають ехосигнали зубами. І кожен зуб розглядається як пасивний резонатор, 
порушуваний відбитим ехосигналом, а зубні нерви - як сенсори звукового тиску ехо. Кожен ряд зубів розглядається як еквідистантна антенна решітка приймачів 3 вузькою характеристикою спрямованості, сигнали якої подаються по зубних нервах прямо в центральну нервову систему (минаючи завиток). Таким чином, наявні літературні дані неоднозначні і суперечливі, а основне питання про звукопровідні шляхи і механізми звукопроведення залишається нез'ясованим. Разом з тим наші попередні дані [2, 5] дають підстави розглядати підборідні отвори як унікальний шлях, по якому звук може проходити у жировий тяж мандибулярного каналу дельфіна. Вивчення морфології нижньої щелепи дельфіна i подальше моделювання підтверджують це припущення і дають підстави вважати, що 3 погляду акустики кожен ряд підборідних каналів являє собою акустичну антену біжучої хвилі, що розташована в горлі катеноїдального акустичного рупора, роль якого відіграє відповідний мандибулярний канал [3-5]. Уявлення про нижню щелепу як про систему 3 двох антен біжучої хвилі пояснює механізми звукопроведення і формування характеристики спрямованості слуху. Виходячи $з$ цього, морфологічні структури кожної з половин нижньої щелепи (підборідні отвори, мандибулярний канал і жировий тяж) розглядаються як компоненти передбачуваного спеціалізованого периферичного відділу підсистеми ехолокаційного слуху.

Мета нашої роботи - дослідження ролі підборідних каналів у слуху дельфіна, конкретні задачі складалися 3 визначення впливу акустичного екранування підборідних каналів на пороги виявлення акустичних імпульсів 3 максимумом енергії на різних частотах.

\section{МЕТОДИКА}

Експерименти проводили на базі Карадазького природного заповідника НАН України в закритому бетонному басейні розміром $23 \times 9 \times 4,5$ м. Як дослідну тварину використовували дорослого чорноморського дельфіна виду афаліна (Tursiops truncatus p.), що раніше не брала участь в акустичних експериментах. Досліди проводили 3 використанням методики інструментальних умовних рефлексів з харчовим підкріпленням, з використанням парадигми go/no-go [18]. Дельфін був навчений за сигналом підходити до містків (5), (рис. 1), де тренер одягав (чи не вдягав) йому акустичний екран на ділянку підборідних каналів (рис. 2). Після цього дельфін за сигналом тренера підходив до стартового маніпулятора, підвішеного на глибині 1 м, i стояв, торкаючись його кінчиком рострума. Через кілька секунд дослідник включав стимул. Якщо стимул пред'являвся, i дельфін його виявляв, то він залишав стартову позицію (go) і натискав рострумом на сигнальний маніпулятор (4), показуючи тим самим, що він виявляв пропонований стимул. Якщо стимул не пред'являвся, то дельфін залишався на стартовій позиції (nо-

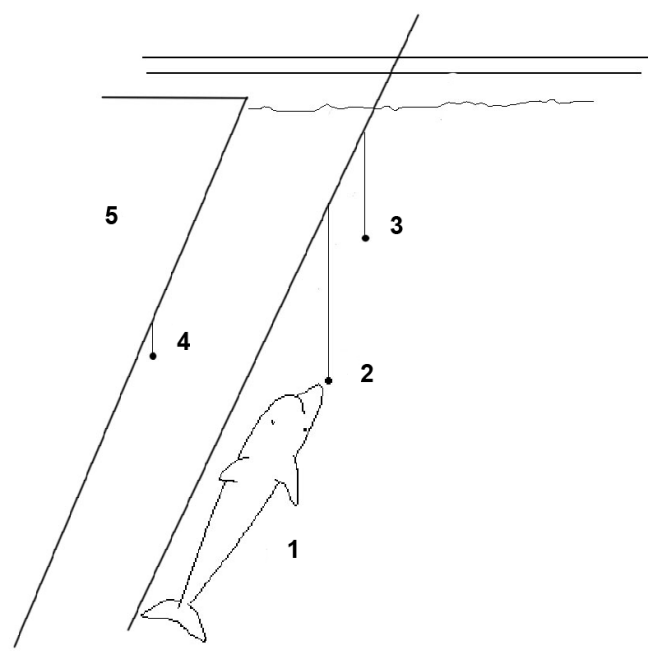

Рис. 1. Конфігурація експерименту: 1 - дельфін у стартовому положенні, 2 - стартовий маніпулятор, 3 випромінювач акустичних стимулів, 4 - сигнальний маніпулятор, 5 - мостки експериментатора. Дельфін, стартовий маніпулятор і випромінювач акустичних стимулів розташовані на глибині 1 м. Сигнальний маніпулятор розташований біля поверхні води. Відстань між випромінювачем і стінкою басейна 3 м, відстань між випромінювачем і стартовим маніпулятором 2 м 
go) до сигналу тренера. У цьому разі дельфін одержував харчове підкріплення за правильне рішення задачі. За необхідності тренер щораз знімав для цього акустичний екран. Помилки (дельфін не підходив до сигнального маніпулятора при наявності сигналу чи підходив при відсутності сигналу, - помилкова тривога) не підкріплювалися. У кожному іспиті пред'явлення позитивного чи негативного стимулів (пред'явлення чи не пред'явлення стимулу) визначалося випадковим порядком (але не більш ніж три однакових стимули підряд). Для визначення порога дельфіну, як правило, давалися кілька десятків пред'явлень. Задачу вважали вирішеною, якщо відсоток правильних відповідей дорівнював чи перевищував $75 \%$.

Для зменшення впливу на результати експериментів інтерференції прямого i відбитих у басейні сигналів як стимули використовувалися короткі широкополосні акустичні імпульсні сигнали. Стимули 3 максимумом енергії на частотах 30 i


сферичних акустичних перетворювачів 3 п'єзокераміки діаметром 50 і 20 мм прямокутними імпульсами тривалістю $17 \mathrm{i}$ 5 мкс відповідно. Для одержання імпульсів 3 максимумом енергії на частотах 8 i 16

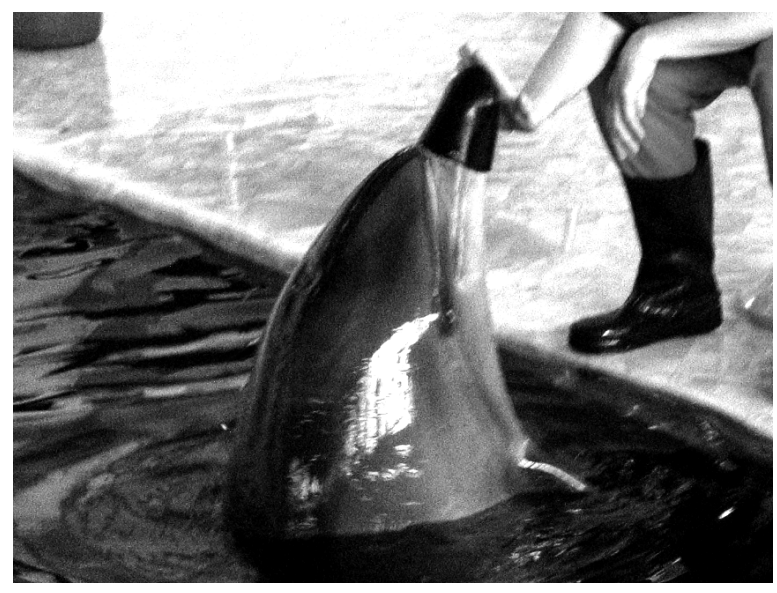

Рис. 2. Дельфін біля містків експериментатора 3 одягненим на рострум акустично непрозорим екраном
кГц використовували випромінювач діаметром 50 мм, що збуджувався прямокутним імпульсом через октавний полосовий фільтр із центральною частотою 8 чи 16 кГц відповідно. Стимули пред'являлися дельфіну протягом 4 с 3 частотою повторень 3 на секунду. Тривалість стимулів не перевищувала 3 періодів відповідної частоти максимуму енергії акустичного імпульсу. У цьому разі відбитки від стін басейну і поверхні води не накладалися на стимул, тому що приходили 3 достатньою часовою затримкою й істотно ослаблені в порівнянні 3 прямим сигналом. При порогових рівнях стимулу відбитки були нижчими від порога виявлення імпульсів, що дало змогу виконати вимірювання без спеціальних звуковбирних покрить.

Акустично непрозорий екран підборідних каналів (див. рис. 2) був виготовлений за формою рострума дельфіна i щільно вдягався на нього, довжина екрана близько 15 см. Екран виготовлений $з$ листа спіненого неопрена з замкнутими порами товщиною 5мм. Цей матеріал має високу міцність, водонепроникний і маслостійкий. У зв'язку з цим може довго зберігати звукоекрануючі властивості, що забезпечуються пухирцями газу, які знаходяться в порах матеріалу. Ефективність екранування матеріалу ( $\delta)$ була визначена перед проведенням досліджень. Зменшення пікового звукового тиску коротких широкополосних імпульсів 3 максимумом енергії на частотах 10, 55 і 170 кГц при екрануванні їх одним шаром цього матеріалу для нормально падаючого звуку сягає 28, 32 і 36 дБ відповідно. Слід зазначити, що довжина хвилі в ділянці частот, використаних в експерименті змінюється від 1,5 до 20 см, тобто акустичний екран на низьких частотах має відносно невеликі лінійні розміри в порівнянні $з$ довжиною хвилі. У зв'язку 3 цим для підвищення ефективності екранування екран мав відповідну форму, закриваючи і верхню і нижню щелепу. Якщо 
екран виконати за формою зовнішньої поверхні нижньої щелепи, то в результаті дифракції навіть на частоті 100 кГц (довжина хвилі 1,5 см) ефективність екрана буде невисокою, а на частоті 8 кГц екранування не буде, тому, що довжина хвилі $(18,75 \mathrm{~cm})$ стає більшою від розмірів екрана.

\section{РЕЗУЛЬТАТИ ТА ЇХ ОБГОВОРЕННЯ}

У роботі були виміряні пороги виявлення дельфіном коротких широкополосних акустичних імпульсів з максимумом енергії на частотах 8, 16, 30 і 100 кГц, і пороги виявлення цих самих імпульсів в умовах акустичного екранування підборідних каналів нижньої щелепи. На рис. 3 представлено відношення середніх значень порогів виявлення акустичних імпульсів при екрануванні підборідних каналів до порогів без екранування - ефективність екранування. Для кращого розуміння отриманих результатів на цьому ж рисунку представлена залежність довжини хвилі від частоти, тому обидві осі ординат лінійні. 3 отриманих результатів випливає, що зі збільшенням частоти максимуму енергії імпульсів (8, 16, 30 і 100 кГц) середні значення порогів виявлення імпульсів при екрануванні підборідних каналів погіршуються в $31,47,91$ і 301 разів (чи на 30 , 34, 40 і 50 дБ) відповідно. Важливо відзначити, що отримані величини порогів виявлення стимулів, узгоджуються 3 аудіограмою пляшконосого дельфіна [8], з урахуванням явища енергетичної сумації $[1,9]$. Отже, дельфін, що використовувався в нашому експерименті, має нормальний слух.

Одержана в експерименті ефективність екранування дуже сильна і на низьких частотах, і на частотах свистових сигналів дельфінів, і в ділянці частот ехолокації, i істотно залежить від частоти. Проте результати вказують на те, що звуки всіх частот проходять по унікальному шляху, через підборідні канали. Тоді як зменшення ефективності екранування підборідних каналів зі зниженням частоти стимулів можна пояснити зростаючим прониканням звуку за екран у результаті дифракції. Довжина хвилі звуку в досліджуваному діапазоні частот зі зниженням частоти істотно зростає (див. рис. 3), і для частот близько 16 кГц лінійний розмір екрана (довжина) стає порівнянний 3 довжиною хвилі, а близько 8 кГц - розміри екрана стають навіть меншими від довжини хвилі. Водночас, як це випливає 3 теорії й отриманих результатів (див. рис. 3, 100 кГц), ефективність екранування залишається високою поки розміри екрана на порядок більші від довжини хвилі. У цьому разі для екрана виконуються умови геометричного розсіювання. Для такого екрана ефективність екранування стає навіть більшою, ніж ефективність екранування матеріалу, 3 якого він виготовлений (див. рис. 3, 100 кГц). Це пов'язано з тим, що звуки падають на нижню щелепу і, відповідно, на екран, майже по дотичній i проходять шлях у матеріалі екрана істотно більший, ніж його

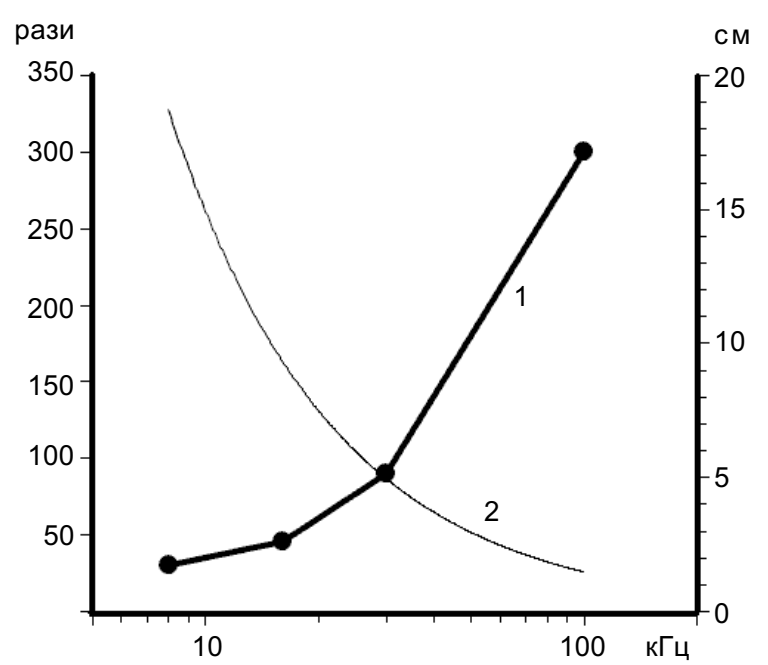

Рис. 3. Залежність середніх значень ефективності акустичного екранування $(\delta), 1$ - ділянки підборідних каналів дельфіна, від частоти максимуму енергії акустичних імпульсів (F), і залежність довжини хвилі звуку у воді $(\lambda), 2$ - від частоти $(\mathrm{F})$ 
товщина. Отже, якщо врахувати вплив дифракції, то стає зрозуміло, що ефективність екранування підборідних каналів на вимірюваних частотах була б однаковою при постійному відношенні розмірів екрана до довжини хвилі. Про це саме говорить i той факт, що величина порогів змінюється обернено пропорційно довжині хвилі (див. рис. 3). На жаль, на низьких частотах важко виконати таке співвідношення, тому що розміри екрана повинні бути занадто великими (наприклад, довжина 1,875 м для частоти 8 кГц), тому зі зниженням частоти ефективність використовуваного екрана зменшується.

Отримані в роботі нові оригінальні результати вказують на те, що підборідні канали являють собою унікальний звукопровідний шлях, по якому звуки в полосі частот приблизно від 6 і до 160 кГц (з огляду на широкополосність стимулів) проходять у жировий тяж мандибулярного каналу. У зв'язку з цим припущення про те, що морфологічні структури нижньої щелепи це спеціалізований периферичний відділ слуху дельфіна $[3,4,5]$, що було засновано на вивченні морфології і результатах моделювання, у світлі отриманих результатів має додаткове експериментальне підтвердження.

I хоча в цій роботі ефективність маскування підборідних каналів на частотах нижче 8 кГц не вимірялася, можна думати, що і на частотах нижче 8 кГц звукопроведення здійснюється по унікальному шляху, через підборідні канали. На користь цього свідчить постійний нахил (9-10 дБ/ окт) низькочастотного схилу аудіограми дельфіна [8], що починається приблизно від 100 Гц і тягнеться аж до 20-30 кГц.

Отже, припущення про можливість звукопроведення через “акустичне вікно" нижньої щелепи, через зовнішні слухові проходи й інші, обговорювані в літературі звукочуттєві ділянки голови дельфіна $[7,13$, 16], виглядають не спроможними.
Водночас підборідні канали, відіграючи роль зовнішніх слухових проходів, проводять весь діапазон звуків слуху дельфіна в жировий тяж мандибулярного каналу. По жировому тяжу звуки передаються на латеральну стінку барабанної кістки і на завиток, що узгоджується 3 роботами [10, $11,14,15]$. Виходячи 3 морфології, можна припустити наявність подібного механізму звукопроведения в Odontoceti.

\section{В. А. Рябов \\ ПОДБОРОДОЧНЫЕ КАНАЛЫ И СЛУХ ДЕЛЬФИНА}

Пороги обнаружения коротких широкополосных акустических импульсов с максимумом энергии на частотах 8,16 , 30 и 100 кГц были измерены в поведенческом эксперименте у дельфина афалина (Tursiops truncatus p.) в закрытом бассейне. Показано, что, при акустическом экранировании подбородочных каналов пороги ухудшаются на 30, 34, 40 и 50 дБ, соответственно. Полученные в работе новые оригинальные результаты указывают на то, что подбородочные каналы представляют собой уникальный звукопроводящий путь, по которому звуки в полосе частот приблизительно от 6 и до 160 кГц (учитывая широкополосность стимулов) проходят в жировой тяж мандибулярного канала. В связи с этим предположение о том, что морфологические структуры нижней челюсти являют собой специализированный периферический отдел слуха дельфина, которое было основано на изучении морфологии и результатах моделирования, в свете полученных результатов имеет дополнительное экспериментальное подтверждение. Подбородочные каналы играют роль наружных слуховых проходов и проводят весь диапазон звуков слуха дельфина в жировой тяж мандибулярного канала. По жировому тяжу звуки передаются на латеральную стенку барабанной кости и на улитку. Исходя из морфологии, можно предположить наличие подобного механизма звукопроведения у Odontoceti.

Ключевые слова: дельфин, слух, подбородочные каналы, жировой тяж, мандибулярный канал, звукопроведение.

\section{V.A. Ryabov}

\section{MENTAL FORAMENS} AND DOLPHIN HEARING

Detection thresholds of short broadband acoustic impulses with an energy maximum on frequencies $8,16,30$ and $100 \mathrm{kHz}$ was measured in the dolphin (Tursiops truncatus p.) with using techniques of behavioral responses in the indoor pool. At acoustic shielding of mental foramens, detection thresholds 
of these impulses worsen on $30,34,40$ and $50 \mathrm{~dB}$, respectively. The new original results obtained experimentally prove that mental foramens are the unique sound-conducting pathway for sounds of about 6-160 kHz frequency band (in consideration of stimulus broadbandness). In this connection the assumption that morphological structures of the lower jaw represent a specialized peripheral part of the dolphin hearing, which was based on studying of morphology and results of modelling, receives additional experimental confirmation. The mental foramens play part of external auditory canals and conduct all frequency range of the hearing of dolphin into fat body of the mandibular canal. Via fat body sounds transmit to a lateral side of an acoustical bone and into the middle and inner ear. From morphology similarity, it is possible to assume presence of the similar sound-conducting mechanism in Odontoceti.

Key words: dolphin, hearing, mental foramens, fat body, mandibular canal, sound-conduction

\section{СПИСОК ЛІТЕРАТУРИ}

1. Бабушина Е.С. Звуковая рецепция морских млекопитающих в зависимости от параметров и путей проведения звука // Биофизика. - 1999. - 44, Вып. 6. - C. 1101-1108.

2. Рябов В.А. Особенности акустического поля мешающих отражений и эхолокационный слух дельфина // Биофизика. “ 2008. “ 53, Вып.3. “ С. 504-512.

3. Ryabov V.A. A dolphin lower jaw is a hydroacoustic antenna of the traveling wave // J. Acoust. Soc. Amer. 2003. - 114, 4. - P. 2414-2415.

4. Ryabov V.A. Lower jaw - peripheric part of the dolphin echolocation hearing. - Moscow: KMK, 2004. P. 483-489.

5. Ryabov V.A. Mechanisms of a dolphin's echolocation hearing. - Bio-Acoustics, 2007. (Fourth Int. Conf. on Bio-Acoustics, Loughborough University, UK) // Proc. Institute Acoustics. - 2007. - 29. Pt. 3. - P. 283-293.

6. Bullock T.H., Grinell A.D., Ikezono E., Kameda K., Katsuki J., Nomota M., Sato O., Suga N., Yanagisawa K. Electrophysiological studies of central auditory mechanisms in cetaceans // Z. Vergl. Physiol. " 1968. 59. - P. 117-156.

7. Brill R.L., Moore P.W.B., Helweg D.A., Dankiewicz
L.A. Investigating the dolphin's peripheral hearing system: acoustic sensitivity about the head and lower jaw // Tehnical report 1865. - 2001. - P. 1-14.

8. Johnson C.S. Sound detection thresholds in marine mammals // Oxford: Pergamon Press, 1967. - P. 247260 .

9. Johnson C.S. Maskes tonal thresholds in the bottlenose porpoise // J. Acoust. Soc. Amer. - 1968. - 44, 4. P. 965-967.

10. Hemila S., Nummela S., Reuter T. A model of the odontocete middle ear // Her. Res. - 1999. - 133. P. 82-97.

11. Koopman H.N., Budge S.M., Ketten D.R., Iverson S.J. Topographical distribution of lipids inside the mandibular fat bodies of Odontocetes: Remarkable complexity and consistency // J. Ocean. Engin. - 2006. 31,1. - P. 95-106.

12. Goodson A.D., Klinowska M. A proposed echolocation receptor for the bottlenose dolphin (Tursiops truncatus): Modeling the received directivity from tooth and lower jaw geometry / Eds. J.A. Thomas, R.A. Kastelein. Sensory abilities of cetaceans: Laboratory and field evidence. - New York: Plenum Press, 1990. P. 255-269.

13. Mwhl B., Au W.W.L., Pawloski J., Nachtigall P.E. Dolphin hearing: Relative sensitivity as a function of point of application of a contact sound source in the jaw and head region // J. Acoust. Soc. Amer. - 1999. 105. - P. 3421-3424.

14. McCormick J.G., Wever E.G., Palin J., Ridgway S.H. Sound conduction in the dolphin ear // J. Acoust. Soc. Amer. - 1970. - 48, 6 (part 2). - P. 1418-1428.

15. Norris K.S. Some problems of echolocation in cetaceans / W. Tavolga. Marine bio-Acoustics. - New York: Pergamon press, 1964. - P. 316-336.

16. Norris K.S. The evolution of acoustic mechanisms in odontocete cetaceans / New Haven. - Lond: Jail Univ. Press, 1968. - P. 297-324.

17. Potter, J.R., Taylor, E.A. On novel reception models for bottlenose dolphin echolocation / Proc. IOA. 2001.23. Pt. 4. - P. 103-112.

18. Schusterman R.J. Behavioral methodology in echolocation by marine mammals / Animal sonar systems. - New York: Plenum Publishing Corp., 1980. - P. 11-41. 